\title{
Protocols for Cloning and Analysis of Blunt-ended PCR-generated DNA Fragments
}

\section{Gina L. Costa and Michael P. Weiner}

Stratagene Cloning Systems, La Jolla, California 92037
Methods are presented for the improved yield and analysis of blunt-ended cloning of PCR-generated DNA fragments. ${ }^{(1)}$ We show that Pfu DNA polymerase polishing of Taq DNA polymerase-generated fragments increases the yield and efficiency of cloning. Using a triple primer set consisting of two outside, asymmetrically distanced primers and one fragment-specific primer, one can determine both the presence and orientation of cloned inserts. Application of these methods allows one to generate and clone a fragment in 1 day and analyze putative clones the next, thereby saving a substantial amount of both time and effort.

\section{VECTOR PREPARATION}

Several vectors and derivatives have been created for PCR cloning. These include the standard pBluescript-type multiple cloning sites (e.g., pBluescriptII, pBC, pCR-ScriptAmp, and pCR-ScriptCam) (Stratagene, La Jolla CA) and the abbreviated multiple cloning sites as contained in the pCR-Script Direct plasmids (Stratagene) ${ }^{(2-4)}$ (see Fig. 1). The abbreviated multiple cloning sites allow the end user to incorporate common restriction enzyme sites into their PCR primer sets without the problem of having the same target sequence occurring in the plasmid vector. It is recommended that the chloramphenicol derivatives be used when subcloning DNA fragments generated from ampicillin-resistance encoding plasmids. This ensures that recombinant colonies after Escherichia coli transformation are not the result of parental plasmid transformation.

\section{Bidirectional Cloning Vectors}

Blunt-ended cloning procedures capture blunted PCR fragments for bidirec-
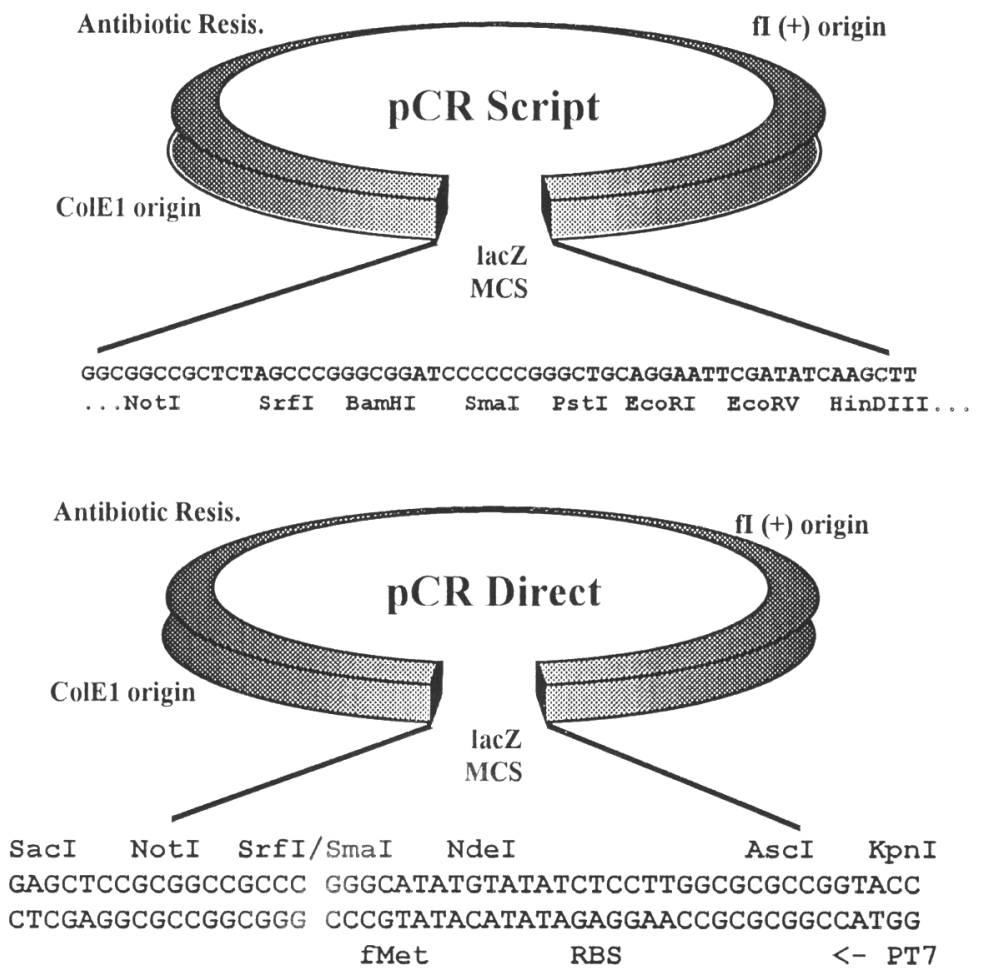

FIGURE 1 Vectors for bidirectional and directional cloning of PCR fragments. Several vectors have been developed for directional and bidirectional cloning. These include derivatives that encode either chloramphenicol or ampicillin resistance with modified multiple cloning sites optimized for specific cloning operations (e.g., general subcloning or protein expression). 
tional insertion. Blunt-ended cloning does not require the addition of extra bases to the primer sets, thereby allowing preexisting primers to be used to generate and clone a DNA fragment. Unfortunately, blunt-ended cloning is an inefficient method with recombinant insertion generally accounting for $<10 \%$ of all transformants (see Fig. 2A). Increases in efficiency are achieved by the inclusion of a restriction enzyme in the ligation reaction as in the pCR-Script method (see Fig. 2B). Preparation of a predigested vector for use in a pCR-Script-type reaction is as follows.

\section{Protocol 1: Preparation of a Bidirectional Cloning Vector}

1. Digest vector DNA with restriction endonuclease in a $20-\mu 1$ reaction mixture containing $\mathrm{dH}_{2} \mathrm{O}$, appropriate buffer, plasmid DNA $(1 \mu \mathrm{g})$, and enzyme (10-20 U). Allow digestion to incubate at the recommended temperature for $1 \mathrm{hr}$. Optional: A $1-\mu \mathrm{l}$ aliquot of the digestion can be run on an agarose gel to check for linearization of vector DNA.

2. Phenol/chloroform extract digestion. Add an equal volume of Tris-buffered phenol, vortex, and transfer the aqueous top phase to a clean tube. Add an equal volume of chloroform, vortex, and transfer the aqueous top phase to a clean tube. Heat-treat extraction at $65^{\circ} \mathrm{C}$ for $15 \mathrm{~min}$ to remove excess chloroform.

3. Precipitate digested, extracted DNA with $0.1 \times$ volume of $10 \mathrm{M}$ lithium chloride $(\mathrm{LiCl})$ and $2.5 \times$ volume of ice-cold $100 \%$ (vol/vol) ethanol, mix, and microcentrifuge at room temperature at $14,000 \mathrm{rpm}$ for $10 \mathrm{~min}$.

4. Following centrifugation, decant supernantant and dry DNA pellet in vacuo for $10 \mathrm{~min}$.

A

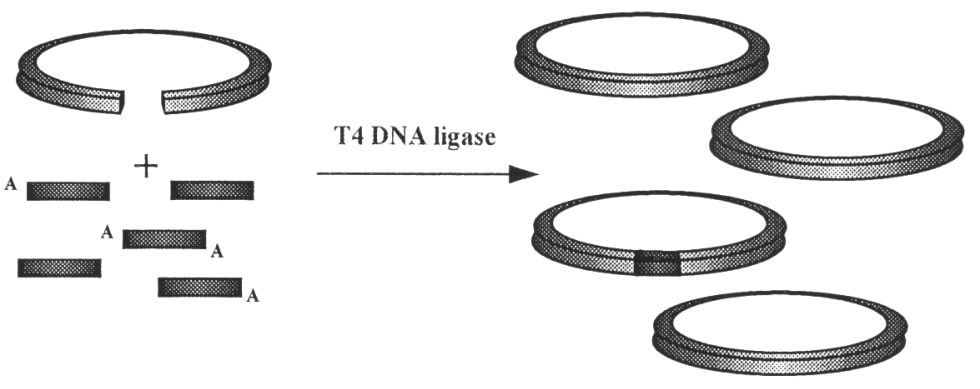

B
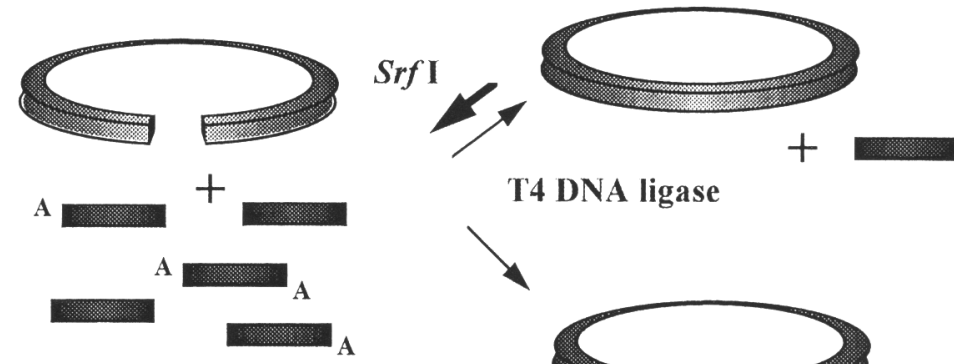

T4 DNA ligase

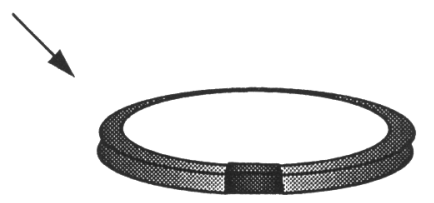

FIGURE 2 Blunt-ended and pCR-Script cloning methods. Methods for standard blunt-ended cloning $(A)$ include incubation of the PCR product with predigested vector DNA and T4 DNA ligase. More efficient methods $(B)$ include the addition of the restriction enzyme (in this example, $S r f l$ endonuclease) to regenerate the linearized vector from the self-ligated vector during the ligation reaction. 


\section{IIIIIIManual Supplement}

5. Resuspend the DNA in $50 \mu \mathrm{l}$ of TE buffer ( $5 \mathrm{mM}$ Tris- $\mathrm{HCl}$ at $\mathrm{pH} 8.0 ; 0.1$ mM EDTA). Final volume of $1 \mu \mathrm{g}$ of predigested DNA $=10 \mathrm{ng} / \mu \mathrm{l}$. The predigested vector can be stored at $4^{\circ} \mathrm{C}$.

\section{Directional Cloning Vectors}

To create a directional cloning method that does not require the addition of extra bases to the primers, we relied on two known facts from previous experimentation. First, T4 DNA ligase requires a $5^{\prime}$ phosphate and a $3^{\prime}$ hydroxyl group to efficiently ligate two strands of DNA together. Second, linear DNA transforms recBC-proficient hosts of $E$. coli at a greatly reduced efficiency (it is decreased by approximately four orders of magnitude). It was therefore reasoned that directional cloning would be achieved if one were to create a monophosphorylated vector and a monophosphorylated insert; then, in the desired orientation, the ligation would result in a nicked, circular, highly transformable molecule; in the undesired, opposite orientation the ligation reaction would result in a linear molecule that transforms with a drastically reduced efficiency.

Creation of a monophosphorylated vector is acheived by enzymatically treating a multiple cloning site with a blunt-end restriction endonuclease, dephosphorylating with alkaline phosphatase, and subsequent digestion with a second blunt-end restriction endonuclease. Degenerate blunt-end restriction endonucleases may be used that can be engineered to recreate a restriction site upon vector ligation following digestion and dephosphorylation steps. Proper DNA sequence manipulation will enable the enzymatically processed vector to be used in a pCR-Script-type reaction, whereby self-ligated vector is susceptible to restriction by the endonuclease present in the ligation reaction. Owing to the importance of recreating a restriction enzyme site following vector self-ligation, the necessity of using highly purified enzymes for performing the directional and bidirectional cloning protocols as described cannot be overstated. ${ }^{(5)}$ Nuclease contamination must be determined and eliminated prior to performing the described experiments. ${ }^{(6)}$

In a specific example, using the pCR-Script Direct directional cloning method, we chose to enzymatically process a multiple cloning site that was engineered to contain both a Srfl (5'-GCCC GGGC-3') and a SmaI (5'-CCC GGG-3') site. ${ }^{(7)}$ Digestion of this vector first with Srfl, dephosphorylation with alkaline phosphatase, and, finally, digestion with SmaI resulted in the desired monophosphorylated vector (see Fig. 3). If the Smal site is of the sequence 5'-TGGG CCCG-3', then the removal of the short DNA fragment created after Srfl-Smal digestion results in retention of a Srfl site. If both enzymes return to the same reading frame, then phenotypic selection can still be used. Creation of a monophosphorylated vector is acheived by the following general guidelines.

\section{Protocol 2: Preparation of a Directional Cloning Vector}

1. Digest vector DNA with the upstream blunt-end restriction endonuclease in a $50-\mu \mathrm{l}$ reaction mixture containing $\mathrm{dH}_{2} \mathrm{O}$, Universal buffer (Stratagene, La Jolla, CA), plasmid DNA ( $1 \mu \mathrm{g})$, and enzyme (20 units). Allow digestion to incubate at the recommended temperature for $1 \mathrm{hr}$. Optional: An aliquot of the reaction can be run on an agarose gel to check for linearization of vector DNA.

Note: A buffer that is compatible with the first restriction endonuclease digestion as well as the alkaline phosphatase dephosphorylation should be used to optimize enzymatic processing of vector DNA.

2. Heat-kill enzyme by incubating reaction at $65^{\circ} \mathrm{C}$ for $20 \mathrm{~min}$. Remove to ice. 


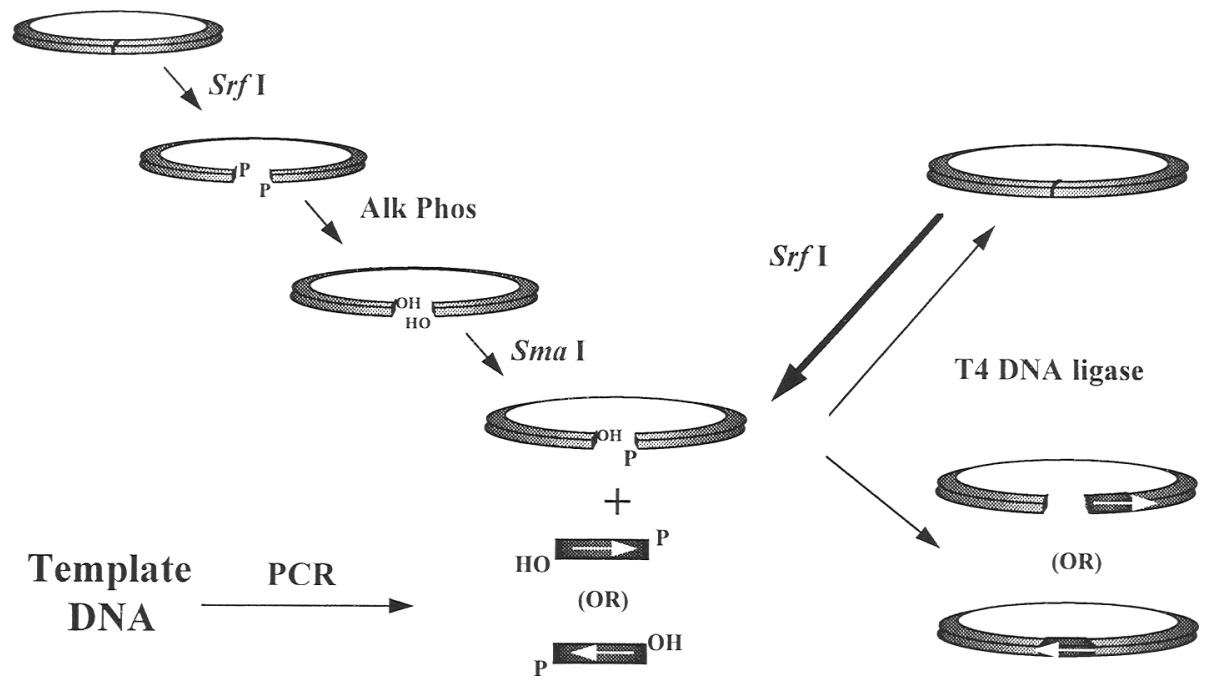

FIGURE 3 Monophosphorylation and pCR-Script Direct cloning. The plasmid pCR-Script Direct is digested with the restriction enzyme Srfl, treated with alkaline phosphatase to remove the $5^{\prime}$ phosphate groups, and then digested with the restriction endonuclease SmaI. Ethanol precipitation was used to remove the small (15-bp) linker. The insert fragment was created using either a machine-synthesized 5'-phosphorylated or kinase-treated primer. The monophosphorylated primer and vector are incubated in the presence of both Srfl and T4 DNA ligase. After room temperature incubation, the DNA was used to transform $E$. coli.

3. Add alkaline phosphatase enzyme (0.1-0.2 units) directly to the heattreated reaction mixture and incubate according to manufacturer's guidelines.

Note: Commercially available preps of molecular biology grade alkaline phosphatase often contain nuclease contamination. We recommend the use of bacterial alkaline phosphatase which has been purified devoid of contaminating nucleases and specifically quality-controlled for use in the pCR-Script assay.

4. Phenol/chloroform extract reaction. Add an equal volume of Tris-buffered phenol, vortex, and transfer the aqueous top phase to a clean tube. Add an equal volume of chloroform, vortex, and transfer the aqueous top phase to a clean tube. Heat-treat extraction at $65^{\circ} \mathrm{C}$ for $15 \mathrm{~min}$ to remove excess chloroform. Remove to ice.

5. Set up a 30- $\mu$ l digestion containing the processed vector DNA with the downstream blunt-end restriction endonuclease by adding a $15-\mu l$ aliquot of the phenol/chloroform-extracted DNA, $\mathrm{dH}_{2} \mathrm{O}$, Universal buffer, (Stratagene) and enzyme (20 units). Allow the digestion to incubate at the recommended temperature for $1 \mathrm{hr}$.

6. Heat-kill enzyme by incubating reaction at $65^{\circ} \mathrm{C}$ for $20 \mathrm{~min}$. Remove to ice.

7. Precipitate the monophosphorylated DNA with $0.1 \times$ volume of $10 \mathrm{M}$ lithium chloride $(\mathrm{LiCl})$ and $2.5 \times$ volume of ice-cold $100 \%$ (vol/vol) ethanol, mix and microcentrifuge at room temperature at $14,000 \mathrm{rpm}$ for $10 \mathrm{~min}$.

8. Following centrifugation, decant supernantant and dry DNA pellet in vacuo for $10 \mathrm{~min}$.

9. Resuspend the DNA in $25 \mu$ l of TE buffer $(5 \mathrm{~mm}$ Tris- $\mathrm{HCl}$ at $\mathrm{pH} 8.0,0.1$ mM EDTA). Final volume of monophosphorylated $D N A=10 \mathrm{ng} / \mu \mathrm{l}$. The monophosphorylated vector can be stored at $4^{\circ} \mathrm{C}$.

\section{INSERT PREPARATION}

\section{PCR Primer Design Considerations}

Recent studies have shown that many species of DNA polymerases (e.g., T7, 
modified T7, Taq, Vent, and Klenow) exhibit terminal deoxynucleotidyl transferase (TdT) activity. ${ }^{(8,9)}$ The 3 '-end nucleotide extension of PCR products by DNA polymerases has been found to be both nucleotide and polymerase-specific. So, for example, Taq DNA polymerase-generated PCR products would be preferentially modified as follows ( + for extension; - for removal):

\begin{tabular}{ll}
$3^{\prime}$-end Nucleotide & $3^{\prime}$-end Extension ${ }^{(9)}$ \\
\hline $\mathrm{A}$ & $+\mathrm{A}$ (at very low efficiency) \\
$\mathrm{C}$ & $+\mathrm{A}>+\mathrm{C}$ \\
$\mathrm{G}$ & $+\mathrm{G}>+\mathrm{A}>+\mathrm{C}$ \\
$\mathrm{T}$ & $-\mathrm{T},+\mathrm{A}$
\end{tabular}

Unfortunately, there appear to be no consistent patterns for which bases were added. Therefore, it cannot be assumed that all DNA polymerases create blunt-ended fragments. However, depending on the DNA polymerase used, the expected 3 '-end nucleotide of the PCR product can be controlled by the 5 '-end nucleotide as determined in the PCR primer design. For example, when bidirectionally cloning Taq-generated PCR products, optimal primer design would be to create a primer set with $5^{\prime}$-end $T$ residues because the assumed PCR products would contain $3^{\prime}$-end A residues that are extended in very low efficiency.

For directional cloning using a monophosphorylated vector, insert monophosphorylation can be achieved by kinase-treating one primer prior to the PCR reaction or, preferably, by synthesizing a PCR primer with a $5^{\prime}$ phosphate group chemically attached. Synthesis of a PCR primer with a 5 '-terminal phosphate group ensures that all single-stranded DNA has been monophosphorylated, hence producing only monophosphorylated PCR products following thermal cycling. Kinase treatment of primers may leave some singlestranded DNA molecules unmodified, hence decreasing the number of monophosphorylated products following PCR, thereby reducing the overall efficiency of directional cloning. The benefit to kinase treatment is that all preexisting primer sets can be modified for use in directional cloning using a monophosphorylated vector. T4 polynucleotide kinase treatment is a simple and rapid procedure that allows for the 5 '-terminal monophosphorylation of a primer that can be used in PCR to produce a monophosphorylated insert in the place of using a prephosphorylated PCR primer.

\section{Protocol 3: Primer-kinasing Treatment}

1. Add the following to a microcentrifuge tube:

$$
\begin{aligned}
& 3 \mu \mathrm{l} \text { of } 10 \times \text { kinase buffer } \\
& 0.5 \mu \mathrm{l} \text { of } 10 \mathrm{~mm} \text { rATP } \\
& 1 \mu \mathrm{l} \text { of T4 DNA kinase (10 units) } \\
& 5 \mu \mathrm{g} \text { of primer } \\
& \hline \mathrm{dH}_{2} \mathrm{O} \text { to a final volume of } 30 \mu \mathrm{l}
\end{aligned}
$$

2. Incubate for $1 \mathrm{hr}$ at $37^{\circ} \mathrm{C}$.

3. Boil the reaction at $95^{\circ} \mathrm{C}$ to denature the T4 DNA kinase.

4. Add the kinased primer and untreated primer to the amplification reaction.

\section{PCR Parameters}

Use of standard conditions will amplify most target sequences, although it is recommended to optimize conditions for each PCR application. As no specific guidelines exist for which buffer conditions to use for the various types of DNA primer-template systems, it is often advantageous to test a range of 
PCR buffers. Recently, a number of PCR buffer optimization kits have been created that contain several different buffer compositions (e.g., Opti-Prime PCR Optimization Kit, Stratagene, La Jolla CA). By modifying the buffer components of a specific reaction, it is possible to improve the yield and specificity of the desired PCR products. When conducting amplification from plasmid DNA, it is advised that circular DNA be linearized to provide a more accessible template molecule. Also, it may be advantageous to perform PCR using varying dilutions of template DNA.

\section{Protocol 4: PCR Amplification}

1. Set up a $100-\mu \mathrm{l}$ reaction in $0.5-\mathrm{ml}$ sterile, autoclaved microcentrifuge tube by adding in order:

\begin{tabular}{ll} 
Microliters & Reagent \\
\hline $75-84$ & $\mathrm{dH}_{2} \mathrm{O}$ (for final volume $\left.=100 \mu \mathrm{l}\right)$ \\
10 & $10 \times$ polymerase buffer (for final $1 \times$ volume) \\
$1-10$ & template DNA $\left(10-500 \mathrm{ng}\right.$ of plasmid DNA or $10^{5}-10^{6}$ \\
& $\quad$ target molecules $\left.{ }^{*}\right)$ \\
2 & dNTP mix $(250 \mathrm{nM}$ each $\mathrm{dNTP})$ \\
1 & $1 \mu \mathrm{g}$ of upstream primer $\left(T_{\mathrm{m}}>55^{\circ} \mathrm{C}\right.$ preferred) \\
1 & $1 \mu \mathrm{g}$ of downstream primer $\left(T_{\mathrm{m}}>55^{\circ} \mathrm{C}\right.$ preferred) \\
1 & DNA polymerase (5 units) \\
\hline
\end{tabular}

Mix well and overlay with approximately $75 \mu \mathrm{l}$ of mineral oil. PCR amplication should be conducted immediately.

*For $3 \times 10^{5}$ targets: $1 \mu \mathrm{g}$ of human single-copy genomic DNA $10 \mathrm{ng}$ of yeast DNA

1 ng of $E$. coli DNA

$1 \%$ of an M13 plaque

2. Perform PCR using the following suggested temperature profile:

$\begin{array}{lrr}\begin{array}{l}\text { Hot start for } n=1 \text { cycle } \\ \text { denaturation }\end{array} & 94^{\circ} \mathrm{C} & 4 \mathrm{~min} \\ \text { primer annealing } & 50^{\circ} \mathrm{C} & 2 \mathrm{~min} \\ \text { primer extension } & 72^{\circ} \mathrm{C} & 2 \mathrm{~min} \\ \begin{array}{l}\text { Follow with } n=25-30 \mathrm{cycles} \\ \text { denaturation }\end{array} & 94^{\circ} \mathrm{C} & 1 \mathrm{~min} \\ \text { primer annealing } & 54^{\circ} \mathrm{C} & 2 \mathrm{~min} \\ \text { primer extension } & 72^{\circ} \mathrm{C} & 1 \mathrm{~min} \\ \begin{array}{l}\text { Extend } n=1 \mathrm{cycle} \\ \text { primer extension }\end{array} & 72^{\circ} \mathrm{C} & 10 \mathrm{~min}\end{array}$

Reactions are stopped by chilling to $4^{\circ} \mathrm{C}$.

3. Following thermal cycling, PCR products should be checked for fidelity and yield by agarose gel analysis. A $10-\mu$ l aliquot of PCR product can be monitored by ethidium bromide staining of the DNA fragments following agarose gel electrophoresis. Known amounts of control DNAs should be run as markers for PCR product size and concentration.

\section{Optional PCR Product Purification}

Removal of excess PCR primers with selective ammonium acetate precipitation before proceding with cloning protocols has been shown to increase the percentage of recombinants. An aliquot of PCR product can be salted out of solution by the following protocol. 


\section{IIIIIIManual Supplement}

Protocol 5: PCR Product Purification

1. Add $0.1 \times$ volume of $10 \times$ STE buffer [ $1 \mathrm{M} \mathrm{NaCl}, 200 \mathrm{~mm}$ Tris- $\mathrm{HCl}(\mathrm{pH}$ 7.5), $100 \mathrm{~mm}$ EDTA].

2. Add an equal volume of $4 \mathrm{M}$ ammonium acetate $\left(\mathrm{NH}_{4} \mathrm{OAC}\right)$ to the sample.

3. Immediately spin in a microcentrifuge at room temperature for $10 \mathrm{~min}$ at $14,000 \mathrm{rpm}$ to pellet DNA.

4. Add $200 \mu \mathrm{l}$ of $70 \%$ ( $\mathrm{vol} / \mathrm{vol})$ ethanol.

5. Spin in a microcentrifuge at room temperature for $10 \mathrm{~min}$ at 14,000 $\mathrm{rpm}$. Carefully decant supernantant. Dry pellet in vacuo.

6. Resuspend the DNA in the same volume that was removed from the PCR using TE buffer [ $5 \mathrm{~mm}$ Tris- $\mathrm{HCl}(\mathrm{pH} 7.5), 0.1 \mathrm{~mm}$ EDTA]. Store at $4^{\circ} \mathrm{C}$ until further use.

\section{End-polishing of PCR Products}

Optimizing primer design in accordance with the specific DNA polymerase used can only minimally increase the number of blunt-ended fragments produced following PCR. The traditional Klenow polymerase should be absolutely avoided for end-polishing because it retains a substantial amount of extendase activity. Fortunately, T4 and Pfu DNA polymerases were found not to exhibit any DNA extendase or TdT activity and can be used to create blunt-ended fragments following PCR. End-polishing has been shown to increase overall recombinant cloning efficiencies. ${ }^{(10)}$ Although it appears that the overall recombinant cloning efficiencies of T4 and $P f u$ DNA polymerases are equivalent, subsequent experimentation has shown that the total number of recombinants ( $\beta$-gal ${ }^{-}$CFUs) is increased upon Pfu polishing. A twofold increase in the number of colonies is generated when $P f u$ polishing is compared with T4 polishing. It appears that T4 DNA polymerase creates bluntended DNA fragments; yet the increased efficiency of $P f u$ DNA polymerasegenerated blunt ends is far superior. Pfu polishing of PCR products generates high-fidelity, blunt-ended DNA fragments in only 30 min using only a small aliquot of PCR product.

\section{Protocol 6: Pfu polishing}

1. Because routine PCR cloning procedures require the use of a small amount of DNA insert (1-4 $\mu \mathrm{l})$, end-polishing reactions can be set up using only $10 \mu \mathrm{l}$ of precipitated PCR product (see above, Optional PCR Product Purification).

2. In an autoclaved, sterile $1.5-\mathrm{ml}$ tube add the following reagents in order:

$$
\begin{aligned}
& 5-10 \mu \text { l of precipitated PCR product } \\
& 1 \mu \mathrm{l} \text { dNTP mix (for final } 100 \mathrm{nM} \mathrm{dNTP} \text { ) } \\
& 1 \mu \mathrm{l} \text { of } 10 \times P f u \text { buffer } \\
& 2 \mu \mathrm{l} \text { of cloned } P f u \text { DNA polymerase (5 units) } \\
& \hline \mathrm{dH}_{2} \mathrm{O} \text { up to } 10 \mu \mathrm{l} \\
& \text { *dNTP mix, cloned } P f u \text { DNA polymerase, and } \\
& \text { Pfu buffer (Stratagene) }
\end{aligned}
$$

3. Add an overlay of mineral oil. Incubate $P f u$-polishing reactions at $72^{\circ} \mathrm{C}$ for $30 \mathrm{~min}$.

4. End-polished DNA fragments can be added directly to ligation reactions. $P f u$-polishing can be conducted directly from the PCR mixture containing dNTPs by aliquoting $10 \mu \mathrm{l}$ of the reaction into a sterile microcentrifuge tube and adding 5 units Pfu DNA polymerase. Incubate sample at $72^{\circ} \mathrm{C}$ for 30 minutes and treat as described above. 


\section{EFFICIENT CLONAL LIGATION AND TRANSFORMATION OF BLUNT-ENDED PCR PRODUCTS}

\section{Ligation Reactions}

To increase the efficiency of blunt-ended cloning of PCR fragments, it was found that a restriction enzyme added in a functional-unit excess relative to the ligase enzyme increases the efficiency of the ligation reaction. ${ }^{(11)}$ This simultaneous restriction digestion and ligation reaction results in an increased efficiency of the blunt-ended cloning by two mechanisms. Primarily, as long as the PCR fragments do not create a restriction enzyme target site, the available linearized vector is removed from the overall reaction by recombinant insertion and an increased amount of linear vector is made available during the ligation reaction by restriction enzyme activity on self-ligated vector molecules. Second, because linear DNA molecules transform $E$. coli at a greatly reduced efficiency, they do not contribute to the number of colonies observed after transformation. This results in a reduced overall transformation efficiency, but because only the linearized, nonrecombinant plasmids are removed, the overall recombinant efficiency actually increases allowing higher densities of cells to be plated.

The pCR-Script method uses the restriction enzyme Srfl for several reasons. ${ }^{(12)}$ First, it has an octanucleotide recognition sequence (5'-GCCC GGGC- $3^{\prime}$ ) that is rare and would occur on average $1 / 65,000 \mathrm{bp}$ (because of the bias against $\mathrm{CpG}$ sequences in mammalian DNA, its actual occurrence is closer to $1 / 100,000 \mathrm{bp}$ ). Second, it is blunt-ended and contains an internal 6-base recognition site that can be recognized by another blunt-ended restriction enzyme (SmaI). This was important in the creation of the pCR-Script Direct method because the actual PCR cloning with directionality occurs in a reaction identical to that described for pCR-Script.

Addition of restriction endonuclease to a ligation reaction allows for an overall fourfold increase in clonal efficiency, along with a greatly reduced background. For the bidirectional cloning of PCR-generated DNA fragments, it is recommended to use a pCR-Script-type reaction containing a predigested vector DNA and Pfu-polished inserts. For the directional cloning of PCRgenerated DNA fragments, it is recommended to use a pCR-Script Direct-type reaction with a monophosphorylated vector and a Pfu-polished monophosphorylated insert. The overall cloning procedure is the same for PCR-Script bidirectional cloning and pCR-Script Direct directional cloning.

\section{Protocol 7: Cloning Procedure}

1. In an autoclaved, sterile $1.5-\mathrm{ml}$ tube set up the pCR-Script reaction by adding the following reagents in order:

$1 \mu \mathrm{l}$ of cloning vector (10 $\mathrm{ng}$ )

$1 \mu$ l of $10 \times$ ligation buffer [ $250 \mathrm{~mm}$ Tris- $\mathrm{HCl}$ ( $\mathrm{pH} 7.5$ ), $100 \mathrm{mM} \mathrm{MgCl}_{2}$, $100 \mathrm{~mm}$ DTT, $200 \mu \mathrm{g} / \mathrm{ml}$ of BSA]

$0.5 \mu \mathrm{l}$ of rATP $(10 \mathrm{~mm})$

2-4 $\mu$ l of $P f u$-polished PCR product insert*

$1 \mu l$ of $S r f$ restriction endonuclease (5 units)

$1 \mu$ l of T4 DNA ligase (4 units)

$\mathrm{dH}_{2} \mathrm{O}$ to a final volume of $10 \mu \mathrm{l}$

*Note: For ligation, ideal ratio of insert-to-vector DNA is variable. For sample DNA, a range from 5:1 to 100:1 insert to vector is recommended. It may be advantageous to optimize conditions for your insert using the following equation:

$$
\text { picomole ends/ } \mu \text { g of DNA }=2 \times 10^{6} / \text { no. of bp }
$$


2. Mix gently and incubate for $1-2 \mathrm{hr}$ at room temperature.

3. Heat-treat sample for $10 \mathrm{~min}$ at $65^{\circ} \mathrm{C}$ (optional).

4. Store the sample on ice until transformation into competent $E$. coli.

\section{E. coli Transformations}

Competent cells are very sensitive to even small variations in temperature and must be stored at $-80^{\circ} \mathrm{C}$. Repetitive freeze-thawing will result in a loss of efficiency and should be avoided. It is important to use Falcon 2059 tubes for the transformation procedure as the critical incubation period during the heat-pulse step is calculated for the thickness and shape of the Falcon 2059 tube. Also, $\beta$-mercaptoethanol has been shown to increase transformation efficiencies two- to threefold. Upon transformation, there seems to be a defined "window" of highest efficiency resulting from the heat-pulse. Optimal efficiencies are observed when cells are heat-pulsed for $45-50 \mathrm{sec}$. Heat pulsing for at least $45 \mathrm{sec}$ to allow for slight variations in the length of incubation is recommended. Efficiencies decrease sharply when incubating for $<45 \mathrm{sec}$ or for $>60 \mathrm{sec}$. Supercompetent cells can be purchased commercially that yield extremely high effiencies upon transformation (e.g., XL1-Blue supercompetent cells, Stratagene).

\section{Protocol 8: Transformation Guidelines}

1. Thaw the competent cells on ice.

2. Gently mix the cells by hand. Aliquot $40 \mu$ l of cells into a prechilled 15-ml Falcon 2059 tube.

3. Add $\beta$-mercaptoethanol (for a final $25 \mathrm{~mm}$ concentration) to the $40 \mu \mathrm{l}$ of bacteria.

4. Swirl gently. Place on ice for $10 \mathrm{~min}$; swirl gently every $2 \mathrm{~min}$.

5. Add $2 \mu \mathrm{l}$ of DNA from heat-treated ligation reaction (Protocol 7 , step 4)

6. Place on ice for $30 \mathrm{~min}$.

7. Heat-pulse in a $42^{\circ} \mathrm{C}$ water bath for $45 \mathrm{sec}$. The length of time of the heat pulse is critical for the highest efficiencies.

8. Place the transformation mixture on ice for $2 \mathrm{~min}$.

9. Add $450 \mu \mathrm{l}$ of preheated $\left(42^{\circ} \mathrm{C}\right) \mathrm{SOC}$ medium and incubate at $37^{\circ} \mathrm{C}$ for $1 \mathrm{hr}$ with shaking at $225-250 \mathrm{rpm}$.

\begin{tabular}{l} 
SOC medium (per liter) \\
\hline 20 grams of tryptone \\
5 grams of yeast extract \\
0.5 gram of $\mathrm{NaCl}$ \\
Water to $900 \mathrm{ml}$ \\
Autoclave \\
Mix the following separately: \\
2.03 grams of $\mathrm{Mg}_{2} \mathrm{Cl}$ \\
1.20 gram of $\mathrm{MgSO}_{4}$ \\
3.60 grams of glucose \\
Add water to a final volume of $100 \mathrm{ml}$ \\
Filter sterilize \\
Add to cooled, autoclaved media
\end{tabular}

10. Plate $50-200 \mu l$ of the transformation mixture $(100 \mu \mathrm{l}$ is standard) using a sterile spreader to place mixture onto the appropriate antibioticcontaining agar plates. Note: If plating $>100 \mu \mathrm{l}$, the cells can be spread directly onto the plates. If plating $\leqslant 100 \mu$ l of the transformation mixture, increase the volume of the transformation mixture to be plated to a total volume of $200 \mu \mathrm{l}$ using SOC medium. 
LB Plates (per liter)

10 grams of $\mathrm{NaCl}$

10 grams of bactotryptone

5 grams of yeast extract

20 grams of bactoagar

Adjust $\mathrm{pH}$ to 7.0 with $5 \mathrm{~N} \mathrm{NaOH}$

Add water to a final volume of 1 liter

Autoclave

Ampicillin-methicillin plates (per liter)

(Use for reduced satillite colony formation)

Prepare LB plates

Autoclave

Cool to $55^{\circ} \mathrm{C}$

Add $20 \mathrm{mg}$ of filter-sterilized ampicillin

Add $80 \mathrm{mg}$ of filter-sterilized methicillin

Chloramphenicol plates (per liter)

Prepare LB plates

Autoclave

Cool to $55^{\circ} \mathrm{C}$

Add $30 \mathrm{mg}$ of filter-sterilized chloramphenicol

11. Incubate plates overnight at $37^{\circ} \mathrm{C}$.

12. Choose white colonies for examination, avoiding colonies with a lightblue appearance or colonies with a blue center. Note: Colonies containing inserts that were initially pure white may turn a very light blue after 2-5 days on the plate.

\section{B-Galactosidase Color Selection}

A phenotypic selection is often used to aid in detecting transformants with the desired inserts. ${ }^{(13)}$ Phenotypic selection by disruption of the $\beta$-galactosidase ( $\beta$-gal) gene is often used to detect recombinants (white colonies on $\mathrm{X}$-gal-containing agar plates) from nonrecombinants (blue colonies on the above plating medium). This selection can be monitored by application of the chromogenic substrate 5-bromo-4-chloro-3-indoyl- $\beta$-D-galactopyranoside $(X$-gal) directly to the plating medium. Isopropyl- $\beta$-D-thio-galactopyranoside (IPTG) is often used in conjunction with X-gal.

\section{Protocol 9: Phenotypic Color Selection}

1. Prepare a $10 \%$ solution of X-gal diluted in dimethylformamide (DMF).

2. Prepare a $100 \mathrm{~mm}$ solution of IPTG diluted in sterile, distilled water.

3. X-gal/IPTG solutions can be spread directly onto antibiotic-containing plates. Note:Avoid mixing IPTG and X-gal, as these chemicals will precipitate.

4. Add a $20-\mu \mathrm{l}$ aliquot of both IPTG and X-gal solutions onto agar plates. Spread immediately in an evenly distributed manner (a slight precipitate may be apparent).

5. Allow plates to dry for $15-30$ min before spreading transformations.

\section{ANALYSIS OF CLONED RECOMBINANTS}

\section{Rapid Recombinant Screening Analysis by PCR}

Recombinant insert analysis of colonies resulting from transformed cells can be performed easily in 1 day using colony-PCR. ${ }^{(14)}$ In this method, primers 
flanking the insert can be used in a PCR containing a colony taken directly from the transformation plate. By using asymmetrically distanced primers, it is possible to discern both insert presence and orientation from the resulting PCR fragment. Alternatively, one can use a triple primer set containing the two asymmetric primers and an additional fragment-specific primer from the primer set used to generate the original fragment (see Fig. 4). Agarose gel analysis of a PCR using such a triple primer set confirms both the presence and the orientation of the cloned insert without the need for further restriction enzyme digestion. Such PCR-mediated analysis allows one to screen numerous clones in a simple, rapid and highly efficient manner.

Traditional DNA Minipreparation and Restriction Enzyme Analysis Alternatively, one could conduct routine plasmid DNA isolation after over-

\section{Recombinant Insert Analysis}

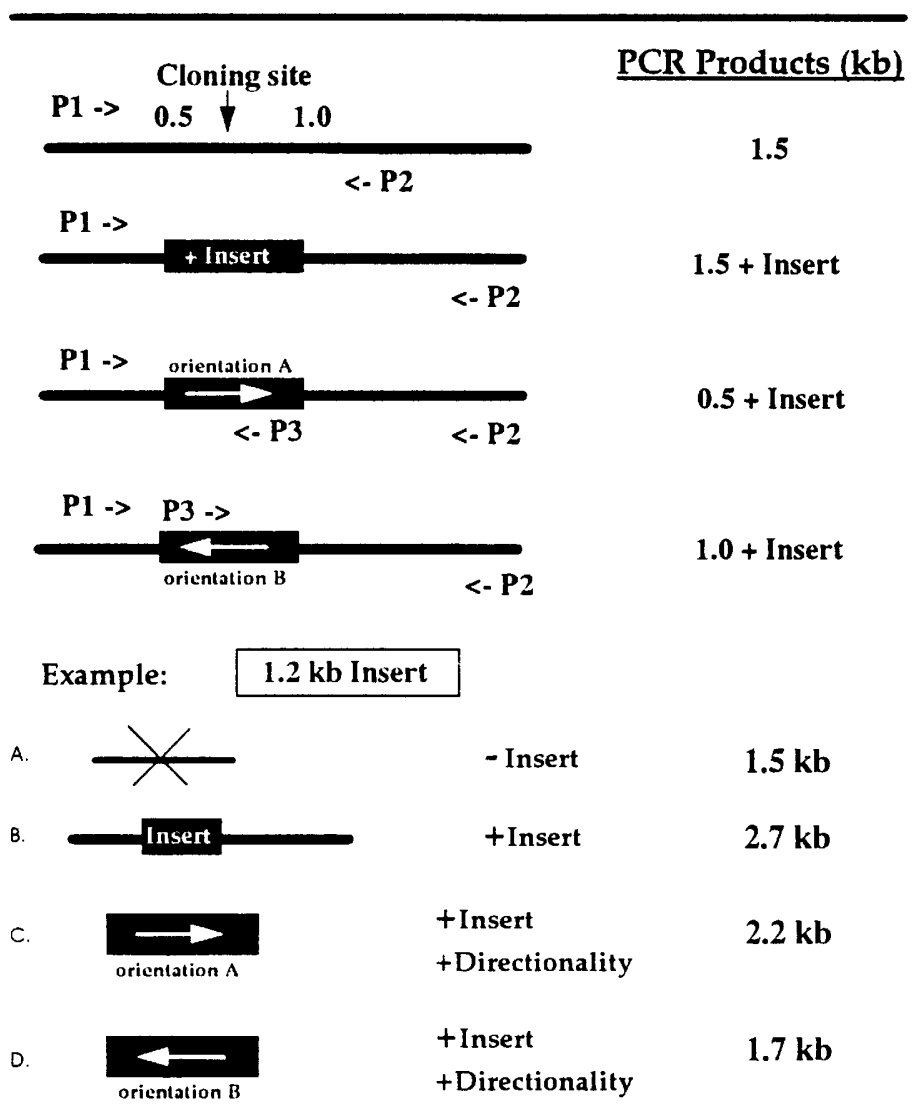

FIGURE 4 Recombinant insert analysis. Schematic representation of PCR products generated using colony PCR to screen for recombinant clones. Verification of a cloned insert is achieved when PCR products using asymmetrically distanced primers (P1 and P2) are analyzed by gel electrophoresis. In a representative experiment where a $1.2-\mathrm{kb}$ insert is cloned into a plasmid DNA, recombinant colonies are picked directly from transformation plates and inoculated into PCR cocktails. Following thermal cycling, agarose gel analysis will yield PCR products indicative of insert presence and orientation. Nonrecombinants that do not contain a cloned insert will exhibit a 1.5-kb PCR product $(A)$, and recombinants containing the $1.2-\mathrm{kb}$ insert will exhibit a 2.7-kb PCR product $(B)$. When PCR-generated fragments are used for cloning, directionality of the cloned insert can be achieved by adding a primer (P3) that was used to generate the cloned insert to the colony PCR cocktail. Recombinants will contain inserts that have been cloned in bidirectionally, and the use of a third primer in the reaction mixture will confirm the orientation of the cloned fragment (orientation $A$ or $B$ ). An example of recombinant screening of clones with a 1.2-kb insert by PCR in the presence of a third primer will reveal orientation of the cloned insert upon gel electrophoresis with either a 2.2-kb $(C)$ or a 1.7-kb $(D)$ PCR product. 
night incubation and determine both insert size and orientation following restriction enzyme digestion and agarose gel analysis. A number of commercially available kits can be used that produce high-quality mini-prep plasmid DNA (e.g., ClearCut Mini-Prep Kit, Stratagene).

\section{CONCLUSION}

PCR has both simplified and accelerated the process one uses for cloning DNA fragments. It is now possible to synthesize primers and perform the PCR, cloning, and transformation reactions in a single day. Analysis of putative clones by colony PCR and cycle sequencing can be completed the following day. We have presented methods that allow PCR cloning operations to exhibit $>50 \%$ recombinant efficiency.

\section{REFERENCES}

1. Costa, G.L., A. Grafsky, and M.P. Weiner. (in prep.).

2. Bauer, J., D. Deely, J. Braman, J. Viola, and M. Weiner. 1992. pCR-Script SK(+) cloning system: A simple and fast method for PCR cloning. Strategies Mol. Biol. 5: 62-65.

3. Costa, G., T. Sanchez, and M. Weiner. 1994. PCR cloning update. Strategies Mol. Biol. (in press).

4. Costa, G., T. Sanchez, and M. Weiner. 1994. pCR-Script Direct SK(+): Directional cloning of blunt-ended PCR products. Strategies Mol. Biol. (in press).

5. Grafsky, A., G. Costa, B. Scott, M. Bergseid, R. Fowler, and M. Weiner. 1994. Highly purified bacterial alkaline phosphatase for use in molecular biological processes. Strategies Mol. Biol. (in press).

6. Grafsky, A., G. Costa, and M. Weiner. (in prep.).

7. Weiner, M.P. 1993. Directional cloning of blunt-ended PCR products. BioTechniques 15: 502505.

8. Clark, J.M. 1988. Novel non-templated nucleotide addition reactions catalyzed by procaryotic and eucaryotic DNA polymerases. Nucleic Acids Res. 16: 9677-9686.

9. Hu, G. 1993. DNA polymerase-catalyzed addition of nontemplated extra nucleotides to the $3^{\prime}$ end of a DNA fragment. DNA Cell Biol. 12: 763-770.

10. Costa, G. and M.P. Weiner. 1994. PCR polishing with Pfu DNA polymerase. Strategies Mol. Biol. (in press).

11. Liu, Z. and L. Schwartz. 1992. An efficient method for blunt-end ligation of PCR products. BioTechniques 12: 28-30.

12. Simcox, T., S. Marsh, E. Gross, W. Lernhardt, S. Davis, and M. Simcox. 1991. Srf I, a new type-II restriction endonuclease that recognizes the octanucleotide sequence, 5'-GCCC/ GGGC-3'. Gene 109: 121-123.

13. Maniatis, T., E. Fritsch, and J. Sambrook. 1982. Molecular cloning: A laboratory manual Cold Spring Harbor Laboratory, Cold Spring Harbor, New York.

14. Costa, G. and M. Weiner. 1994. Recombinant insert analysis using asymmetrically distanced primers. Strategies Mol. Biol. (in press). 


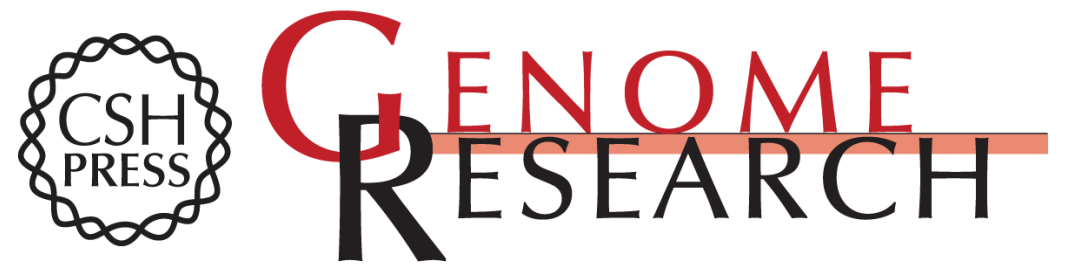

\section{Protocols for cloning and analysis of blunt-ended PCR-generated DNA fragments.}

G L Costa and M P Weiner

Genome Res. 1994 3: S95-S106

\section{License}

Email Alerting

Receive free email alerts when new articles cite this article - sign up in the box at the Service top right corner of the article or click here.

\section{Affordable, Accurate Sequencing.}

